\title{
A social work study on relationship between parenting styles and career aspirations as well as psychological well-being
}

\author{
Atefeh Arab $^{a^{*}}$, Najmeh Sedrpoushan ${ }^{\mathrm{b}}$ and Afsaneh Javadzade
}

${ }^{a}$ MS Student, Counseling Department, Islamic Azad University of Khomeinishahr, Khomeinishahr Branch, Daneshjou Blvd, Iran

${ }^{b}$ Assistant Professor, Counseling Department, Islamic Azad University of Khomeinishahr, Khomeinishahr Branch, Daneshjou Blvd, Iran

${ }^{c}$ Assistant Professor, Counseling Department, Islamic Azad University of Khomeinishahr, Khomeinishahr Branch, Daneshjou Blvd, Iran

\section{H R O N I C L E}

Article history:

Received March 12, 2013

Received in revised format

10 June 2013

Accepted 22 June 2013

Available online

June 252013

Keywords:

Parenting style

Career aspiration

Gender

Baumrind test

Gottfredson test

\section{A B S T R A C T}

\begin{abstract}
We present a social work study on relationship between parenting styles and career aspirations as well as psychological well-being among third year high school female students in city of Khomeinishahr, Iran during the year of 2012. The study selects a sample of 300 students from 1260 female students who were enrolled in third year high school education, randomly. The study uses the Baumrind's questionnaire on parenting style, which consists of 30 questions which equally measure three parenting styles including authoritarian, indulgent and authoritative in Likert scale. The survey also uses Gottfredson's questionnaire to examine occupational aspirations. The study examines whether there is any relationship between parenting style from one side and three personal characteristics including gender, career aspiration and wishes type on the other side. Using Chi-Square technique, the survey examines three hypotheses and the results confirm all three hypotheses of the survey.
\end{abstract}

(C) 2013 Growing Science Ltd. All rights reserved.

\section{Introduction}

One of the primary concerns among many third year students is to plan for their future jobs and build proper plan for lives. There are several studies on finding the relationship between career aspirations and people personal characteristics as well as parenting style. Helwig et al. (2001), for instance, examined career aspirations of a longitudinal sample of students over a ten-year period, from grade 2 to grade 12. They used Gottfredson's theory of career development (1981) and from social learning theory (Lent et al., 1994) to examine their hypotheses. They reported that the social value of children's occupational aspirations increased into the early high school years and began to fall by their senior year in high school when internal, unique personal factors became clear in occupational aspirations as Gottfredson would predict. Through eighth grade, about $40 \%$ of boys and up to $20 \%$ of girls held occupational aspirations classified as fantasy. They recommended that children would 
relinquish fantasy career aspirations with age because of self-awareness and knowledge of the world of work. This change was clear as a substantial shift toward more realistic occupational aspirations occurred during the late high school years.

Lent et al. (1994) developed social cognitive framework of interest development, choice, and performance in occupational development. The framework was extracted primarily from Bandura's (1986) general social cognitive theory. The concentration was on self-efficacy, expected outcome, and objective mechanisms and how they could interrelate with other person (e.g., gender), contextual (e.g., support system), and experiential/learning factors. They explained how hypothesized relationships had been charted in past research. Estep and Olson (2011) investigated parenting style, academic dishonesty, and infidelity in college students and reported similar results with other researchers reported in the literature.

Lerdpornkulrat et al. (2010) stated the importance of for Thailand to promote students' engagements in science, engineering and related professions. They reviewed of the research associated with high school students' career aspirations for science, mathematics, engineering and related professions. They concluded the crucial importance of parenting styles shaping students' career aspirations and engagements in science learning.

Finkelhor and Asdigian (1996) argued that there were some personal characteristics put youth at risk, not through any lifestyle or routine activity mechanism, but by making certain youth more 'congruent' with the requirements or reactivities of potential offenders. Using data from a national youth survey, they examined variables measuring such aspects of target congruence end explained that they make a substantial contribution over and above lifestyle variables alone in forecasting nonfamily and parental assault. Trice et al. (1995) in their survey confirmed that the idea that identification with a parent's work was particularly strong among younger children.

Chen et al. (2000) in their survey on some children reported that parenting styles might be a function of child gender and change with age. Regression analyses disclosed that parenting styles of fathers and mothers predicted various outcomes. Whereas maternal warmth had substantial contributions to the prediction of emotional adjustment, paternal warmth substantially forecasted later social and school achievement.

According to Cripps and Zyromski (2009), Adolescence is a critical period of development. Previous research recommented parent involvement in school directly influences student success. However, various kinds of parental involvement and the attempts of middle school personnel to educate parents about these effective practices had received scant attention in the literature. They reviewed research associated with (a) adolescents' perceptions of parental involvement, (b) the parenting style associated with higher levels of psychological wellbeing, and (c) the effect of assorted parenting styles on adolescent psychological well-being. They concluded with implications for middle school systems, middle school counselors, families, parents, and community members.

\section{The proposed study}

The proposed study of this paper presents a social work study on relationship between parenting styles and career aspirations as well as psychological well-being among third year high school female students in city of Khomeinishahr, Iran during the year of 2012. There were 14 high schools in this city with 1260 third year high school students. Therefore, the sample size is calculated as follows, 
$n=\frac{N \times z_{\alpha / 2}^{2} \times p \times q}{\varepsilon^{2} \times(N-1)+z_{\alpha / 2}^{2} \times p \times q}$,

where $N$ is the population size, $p=1-q$ represents the yes/no categories, $z_{\alpha / 2}$ is CDF of normal distribution and finally $\varepsilon$ is the error term. Since we have $p=0.5, z_{\alpha / 2}=1.96$ and $N=1260$, the number of sample size is calculated as $n=300$. The study selects a sample of 300 students from 1260 female students who were enrolled in third year high school education, randomly. In our study, there were 14 high school and each school consisted of 5 third-year classes. Therefore, we have decided to choose 2 classes out of 5 schools and we have distributed the questionnaires among them.

The study uses the Baumrind's questionnaire (Baumrind, 1972) on parenting style, which consists of 30 questions which equally measure three parenting styles including authoritarian, indulgent and authoritative in Likert scale. The survey also uses Gottfredson's questionnaire (Gottfredson, 1981) to examine occupational aspirations. All participants were female third-year students aged 16-18 with mean of 17.11. They were enrolled in three different educational programs including 178(59.3\%) in science, 64(21.6\%) in humanities and 58(19.1\%) were enrolled in math. The mothers of these high school students were aged 28-48 with a mean of 37.24. Fig. 1 demonstrates educational backgrounds of these mothers. Cronbach alpha for all questions were above 0.85 , which validates the overall survey.

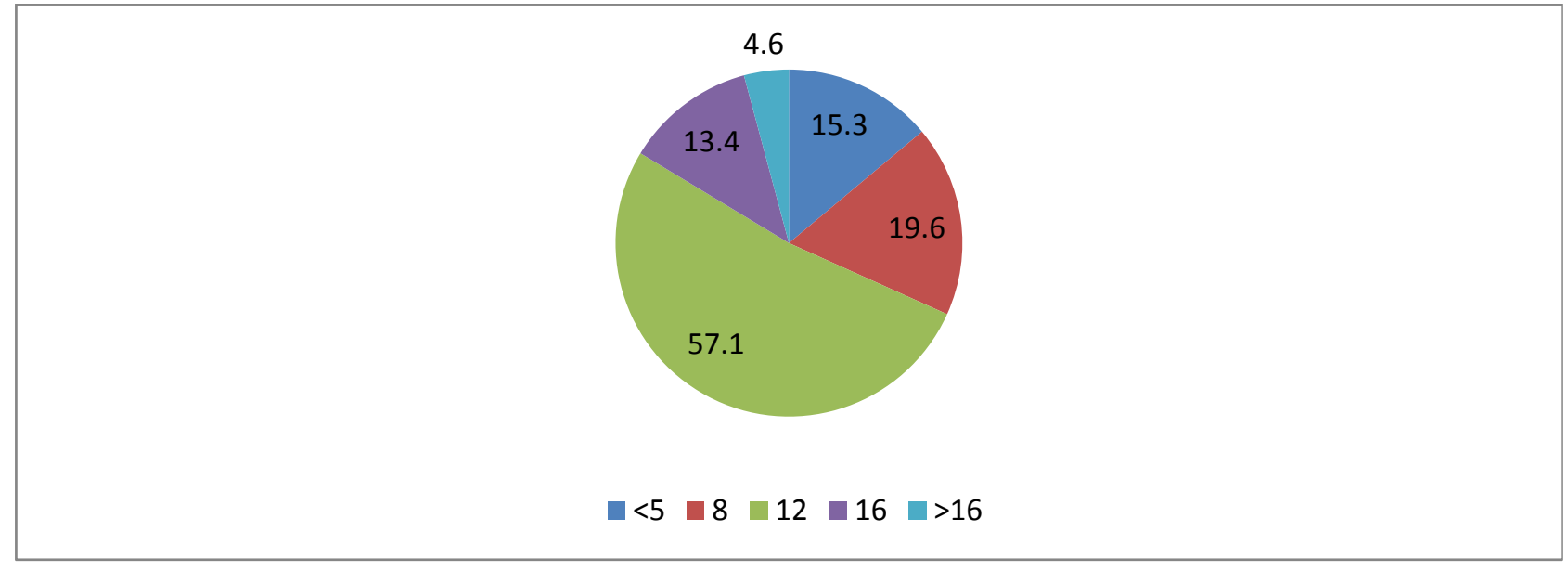

Fig. 1. Basic statistics of the high school students' mothers' years of education

Table 1 demonstrates the summary of various components of the survey.

\section{Table 1}

Basic statistics on different components of the parenting style and psychological well-being

\begin{tabular}{lccc}
\hline Variable & Number & Mean & Standard deviation \\
\hline indulgent & 300 & 98.24 & 4.5 \\
authoritarian & 300 & 56.19 & 12.7 \\
authoritative & 300 & 7.29 & 63.4 \\
Psychological Well-Being & 300 & 43.3 & 54.9 \\
Self-acceptance component & 300 & 13.37 & 50.3 \\
Positive relations with others & 300 & 56.44 & 78.5 \\
Autonomy & 300 & 23.36 & 23.3 \\
Dominate the environment & 300 & 79.36 & 83.7 \\
Living with Purpose & 300 & 64.49 & 14.3 \\
Personal growth & 300 & 11.32 & 20.4 \\
\hline
\end{tabular}

In addition, Table 2 demonstrates the mean and standard deviation association with career aspiration. 
Table 2

Basic statistics associated with career aspiration

\begin{tabular}{lccc}
\hline Variable & Mean & Standard deviation & Number \\
\hline Realism & 0.34 & 0.11 & 300 \\
Search oriented & 0.48 & 0.23 & 300 \\
Art & 0.16 & 0.13 & 300 \\
Social & 0.37 & 0.08 & 300 \\
Initiative & 0.16 & 0.12 & 300 \\
Contract & 0.22 & 0.06 & 300 \\
High Prestige & 0.65 & 0.17 & 300 \\
Average Prestige & 0.27 & 0.12 & 300 \\
Low Prestige & 0.07 & 0.04 & 300 \\
Male oriented & 0.53 & 0.19 & 300 \\
Female oriented & 0.47 & 0.15 & 300 \\
Neutral & 0.21 & 0.11 & 300 \\
\hline
\end{tabular}

The proposed study of this paper considers the following three hypotheses,

1. There is a relationship between parenting style and career aspiration in terms of gender.

2. There is a relationship between parenting style and career aspiration in terms of prestige.

3. There is a relationship between parenting style and career aspiration in terms of types of wishes.

The study uses Chi-Square test to examine different hypotheses of the survey.

\section{The results}

In this section, we present details of our findings on testing different hypotheses.

\subsection{Parenting and gender}

The first hypothesis of this survey considers whether there is any relationship between parenting style and career aspiration in terms of gender. Table 3 shows details of our findings.

\section{Table 3}

The summary of the expected versus observed numbers of parenting and gender

\begin{tabular}{|c|c|c|c|c|c|}
\hline Parenting style & Frequency & Female & Male & neutral & Total \\
\hline \multirow[t]{2}{*}{ Indulgent } & Observed & 18 & 28 & 13 & 59 \\
\hline & Expected & 17.7 & 27.33 & 13.97 & 59 \\
\hline \multirow[t]{2}{*}{ Authoritarian } & Observed & 24 & 42 & 21 & 87 \\
\hline & Expected & 26.1 & 40.31 & 20.59 & 87 \\
\hline \multirow[t]{2}{*}{ Authoritative } & Observed & 48 & 69 & 37 & 154 \\
\hline & Expected & 46.2 & 71.36 & 36.44 & 154 \\
\hline \multirow[t]{2}{*}{ Total } & Observed & 90 & 139 & 71 & 300 \\
\hline & Expected & 90 & 139 & 71 & 300 \\
\hline
\end{tabular}

Chi-Square $=1.063 \mathrm{df}=4 \mathrm{Sig} .=0.03$

The results of Chi-Square test is significance with $\alpha=0.05$, which means we can reject the null hypothesis and conclude that there is a meaningful relationship between parenting style and career aspiration in terms of gender.

\subsection{Parenting and prestige}

The second hypothesis of this survey considers whether there is any relationship between parenting style and career aspiration in terms of prestige. 
Table 4

The summary of the expected versus observed numbers of parenting and prestige

\begin{tabular}{llcccc}
\hline Parenting style & Frequency & high & medium & Low & Total \\
\hline Indulgent & Observed & 31 & 19 & 9 & 59 \\
& Expected & 30.87 & 19.86 & 8.26 & 59 \\
\hline \multirow{2}{*}{ Authoritarian } & Observed & 48 & 26 & 13 & 87 \\
& Expected & 45.53 & 29.29 & 12.18 & 87 \\
\hline \multirow{2}{*}{ Authoritative } & Observed & 78 & 56 & 20 & 154 \\
& Expected & 80.59 & 51.86 & 21.56 & 154 \\
\hline \multirow{2}{*}{ Total } & Observed & 157 & 101 & 42 & 300 \\
& Expected & 157.0 & 101.0 & 42.0 & 300 \\
\hline
\end{tabular}

Chi-Square $=1.20 \mathrm{df}=4$ Sig. $=0.04$

Table 4 shows details of our findings. The results of Chi-Square test is significance with $\alpha=0.05$, which means we can reject the null hypothesis and conclude that there is a meaningful relationship between parenting style and career aspiration in terms of prestige.

\subsection{Parenting and wishes characteristics}

The third hypothesis of this survey considers whether there is any relationship between parenting style and career aspiration in terms of wishes. Table 5 shows details of our findings.

\section{Table 5}

The summary of the expected versus observed numbers of parenting and wishes

\begin{tabular}{llcccccccc}
\hline Parenting style & Frequency & Contract & initiative & Social & Art & Search & Realism & Total \\
\hline Indulgent & Observed & 8 & 6 & 18 & 11 & 9 & 7 & 59 \\
& Expected & 12.19 & 7.67 & 14.16 & 6.10 & 9.44 & 9.44 & 59 \\
\hline \multirow{2}{*}{ Authoritarian } & Observed & 24 & 8 & 18 & 6 & 11 & 20 & 87 \\
& Expected & 17.98 & 11.31 & 20.88 & 9 & 13.92 & 13.92 & 87 \\
\hline \multirow{2}{*}{ Authoritative } & Observed & 30 & 25 & 36 & 14 & 28 & 21 & 154 \\
& Expected & 31.82 & 20.02 & 36.96 & 15.91 & 24.64 & 24.64 & 154 \\
\hline \multirow{2}{*}{ Total } & Observed & 62 & 39 & 72 & 31 & 48 & 48 & 300 \\
& Expected & 62 & 39 & 72 & 31 & 48 & 48 & 300 \\
\hline
\end{tabular}

Chi-Square $=17.59 \mathrm{df}=10 \mathrm{Sig} .=0.02$

The results of Chi-Square test is significance with $\alpha=0.05$, which means we can reject the null hypothesis and conclude that there is a meaningful relationship between parenting style and different kinds of career aspiration.

\section{Conclusion}

In this paper, we have presented an empirical investigation to study the relationship between parenting style and different personal characteristics. The survey has accomplished in one of Iranian city and using two well-known questionnaires, the study has confirmed that there were some meaningful relationships between parenting style and personal characteristics such as gender, prestige and wishes.

\section{Acknowledgment}

The authors would like to thank the people who cordially participated in our survey.

\section{References}

Baumrind, D. (1972). An exploratory study of socialization effects on black children: Some blackwhite comparisons. Child Development, 261-267. 
Chen, X., Liu, M., \& Li, D. (2000). Parental warmth, control, and indulgence and their relations to adjustment in Chinese children: A longitudinal study. Journal of Family Psychology, 14(3), 401.

Cripps, K., \& Zyromski, B. (2009). Adolescents' psychological well-being and perceived parental involvement: Implications for parental involvement in middle schools. RMLE Online, 33(4), 1-14.

Estep, H. M., \& Olson, J. N. (2011). Parenting style, academic dishonesty, and infidelity in college students. College Student Journal, 45(4), 830-838.

Finkelhor, D., \& Asdigian, N.L. (1996). Risk factors for youth victimization: Beyond a lifestyles/routine activities theory approach. Violence and Victims, 11(1), 3-19

Gottfredson, L. S. (1981). Circumscription and compromise: A developmental theory of occupational aspirations. Journal of Counseling psychology, 28(6), 545.

Helwig, A. A. (2001). A test of Gottfredson's theory using a ten-year longitudinal study. Journal of Career Development, 28(2), 77-95.

Lent, R. W., Brown, S. D., \& Hackett, G. (1994). Toward a unifying social cognitive theory of career and academic interest, choice, and performance. Journal of vocational behavior. 45(1), 79-122.

Lerdpornkulrat, T., Koul, R., \& Sujivorakul, C. (2010). Career aspiration and the influence of parenting styles: A review of the literature. Paper presented at the International Conference on Education and Educational Technologies - Proceedings, 71-76.

Trice, A. D., Hughes, M. A., Odom, C., Woods, K., \& McClellan, N. C. (1995). The origins of children's career aspirations: IV. Testing hypotheses from four theories. The Career Development Quarterly, 43(4), 307-322. 